\title{
ANALISIS PUTUSAN PIDANA BERSYARAT DALAM KASUS PENGANIAYAAN ANAK DI BAWAH UMUR (STUDI PUTUSAN NOMOR 2298/PID.SUS/2012/PN.TNG)
}

\section{Legita}

(Mahasiswa Fakultas Hukum Universitas Tarumanagara)

(Email: legitagita@hotmail.com)

\section{Dr. Mety Rahmawati, S.H., M.H. \\ (Corresponding Author)}

(Dosen Tetap Universitas Trisakti, Mengajar Hukum Pidana di Universitas Trisakti, Universitas

Tarumanagara, Meraih Gelar Sarjana Hukum dan Doktor di Universitas Trisakti dan Program

Pascasarjana di Universitas Tarumanagara)

(Email: mety.r@trisakti.ac.id)

\begin{abstract}
Abstrak
Criminal penalty is a criminal under certain conditions. Conditional criminal provisions are regulated in Article 14a-f of the Criminal Code. The case of persecution of the case Number $2298 /$ Pid.Sus / 2012 / Pn.Tng, the judge ruled the conditional penalty against the perpetrator, then the problem in this research is: How qualification can be terminated as a conditional in case of maltreatment in the case Number 2298 / PID.SUS / 2012 /PN.TNG? What is the legal protection of the victim? Method used by normative juridical with supported by interview. There is no special qualification for the perpetrators of such crimes that should be condemned. The judge may decide on a conditional penalty based only on Article 14 a-f of the Criminal Code. In this case the judge's decision has fulfilled the criteria for the stipulation of a conditional penalty because the sentence does not exceed 1 (one) year. The form of legal protection for children victims of the crime of torture of their legal instruments has been regulated in several laws and regulations namely Article 14c of the Criminal Code and Article 71D of Law Number 35 Year 2014 on Child Protection jo Government Regulation Number 43 Year 2017, that every child who becomes victims of criminal offenses are entitled to restitution or indemnification. Although legal instruments provide opportunities for victims to claim compensation to the perpetrator, this opportunity is not used. The victim only requires the perpetrator to be severely punished, thus ignoring the compensation claim.
\end{abstract}

Keywords: Judge's verdict, conditional penalty, abuse of minors, restitution 


\section{PENDAHULUAN}

\section{A. Latar Belakang}

Negara Kesatuan Republik Indonesia (NKRI) adalah negara hukum. ${ }^{1}$ Penegasan ketentuan konstitusi ini bermakna, bahwa segala aspek kehidupan dalam kemasyarakatan, kenegaraan dan pemerintahan harus senantiasa berdasarkan atas hukum. Hukum memiliki tujuan untuk menciptakan ketertiban, ketentraan, kedamaian, kesejahteraan dan kebahagiaan dalam berkehidupan bermasyarakat. Selain itu, hukum sebagai sarana untuk mencari keadilan dan menentukan siapa yang bersalah dan siapa yang benar melalui keputusan hakim yang dijatuhkan kepada pelaku kejahatan. ${ }^{2)}$

Mengingat hukum itu mempunyai sifat mengatur dan memaksa, yaitu mengatur kehidupan masyarakat dengan menuangkannya dalam peraturan perundang-undangan yang telah ditetapkan oleh negara, kemudian peraturan itu dapat dipaksakan kepada setiap orang yang melanggar peraturan tersebut dengan memberikan sanksi yang tegas atau hukuman bagi siapa saja yang tidak menaatinya. Berdasarkan pemahaman tersebut, maka hukum itu bertujuan menjamin adanya kepastian hukum dalam masyarakat dan hukum itu harus pula bersendikan keadilan, yaitu asas-asas keadilan dari masyarakat itu. ${ }^{3)}$

Menurut Binsar M. Gultom, kepastian hukum berbeda dari kepastian keadilan. Kepastian keadilan adalah syarat formal yang harus dipenuhi semua pihak, termasuk aparat penegak hukum sesuai yang diatur dalam undang-undang. Kepastian keadilan merupakan syarat materiil (fakta sesungguhnya). Jika syarat formil telah terpenuhi, menjadi kewajiban hakim untuk mencari, menggali dan menemukan hukum berdasarkan nilai-nilai yang hidup dalam masyarakat untuk selanjutnya dirumuskan dalam pertimbangan putusannya (motivering vonis). ${ }^{4)}$

Sebagai negara hukum, maka bagi siapa saja yang bersalah harus mempertanggungjawabkan perbuatannya. Orang yang memenuhi semua unsur-

\footnotetext{
1) Undang-Undang Dasar Negara Republik Indonesia Tahun 1945, Pasal 1 Ayat (3).

2) Agus Santoso, Hukum, Moral dan Keadilan, Cetakan ke-2, (Jakarta: Kendana Prenada Media Group, 2014), hal. 79.

3) Ibid, hal. 82.

4) Binsar M. Gultom, Pandangan Kritis Seorang Hakim dalam Penegakan Hukum di Indonesia, Cetakan Pertama, (Jakarta: Kompas Gramedia, 2012), hal. 13.
} 
unsur suatu delik seperti yang telah ditentukan dalam undang-undang baik itu merupakan unsur-unsur subjektif ataupun unsur-unsur objektif, tanpa memandang apakah keputusan untuk melakukan tindakan pidana tersebut timbul dari dirinya atau timbul karena digerakkan oleh pihak ketiga bertanggungjawab atas tindakannya itu yang prosesnya diputus oleh hakim di pengadilan.

Salah satu jenis tindak pidana yang sering terjadi dalam kehidupan bermasyarakat adalah penganiayaan terhadap anak yang di dalam Pasal 80 Undang-Undang Nomor 17 Tahun 2016 tentang Perubahan Kedua atas UndangUndang Nomor 23 Tahun 2002 tentang Perlindungan Anak:

(1) Setiap orang yang melakukan kekejaman, kekerasan atau ancaman kekerasan, atau penganiayaan terhadap anak, dipidana dengan pidana penjara paling lama 3 (tiga) tahun 6 (enam) bulan dan/atau denda paling banyak Rp 72.000.000,00 (tujuh puluh dua juta rupiah).

(2) Dalam hal anak sebagaimana dimaksud dalam ayat (1) luka berat, maka pelaku dipidana dengan pidana penjara paling lama 5 (lima) tahun dan/atau denda paling banyak Rp 100.000.000,00 (seratus juta rupiah).

(3) Dalam hal anak sebagaimana dimaksud dalam ayat (2) mati, maka pelaku dipidana dengan pidana penjara paling lama 10 (sepuluh) tahun dan/atau denda paling banyak Rp 200.000.000,00 (dua ratus juta rupiah).

(4) Pidana ditambah sepertiga dari ketentuan sebagaimana dimaksud dalam ayat (1), ayat (2), dan ayat (3) apabila yang melakukan penganiayaan tersebut orang tuanya.

Upaya untuk menjamin penegakan hukum harus dilaksanakan secara benar, adil, tidak ada kesewenang-wenangan, tidak ada penyalahgunaan kekuasaan, ada beberapa asas yang harus selalu tampil dalam setiap penegakan hukum, yaitu asas tidak berpihak (impartiality), asas kejujuran dalam memeriksa dan memutus (fairness), asas beracara benar (procedural due process), asas menerapkan hukum secara benar yang menjamin dan melindungi hak-hak substantif pencari keadilan dan kepentingan sosial (lingkungan), asas jaminan bebas dari segala tekanan dan kekerasan dalam proses peradilan. Sistem peradilan pidana sebagai pelaksanaan dan penyelenggaraan penegakan hukum terdiri dari 
beberapa badan yaitu kepolisian, kejaksaan, pengadilan dan lembaga pemasyarakatan, yang saling berhubungan antara satu dengan yang lainnya. ${ }^{5)}$

Tindak pidana penganiayaan anak di bawah umur dalam perkara Putusan Nomor 2298/Pid.Sus/2012/PN.TNG, dilakukan oleh seorang ibu yang berinisial (V) dan anaknya yang berinisial (AR) secara bersamaan terhadap seorang anak dibawah umur yang diketahui teman sekolah dari (AR) yang berinisial (LA). Akibat dari penganiayaan tersebut LA selaku korban menderita luka memar di bagian muka dan kelompak mata sebagaimana hasil Visum Et Refertum Nomor: P.002/VER/MRD/III/2012.

Pelaku dijerat dengan Pasal 80 Ayat (1) Undang-Undang Nomor 23 Tahun 2002 tentang Perlindungan Anak jo Pasal 55 Ayat 1 ke-1 KUHP yang ancaman pidana penjara paling lama 3 (tiga) tahun 6 (enam) bulan dan/atau denda paling banyak Rp 72.000.000,00 (tujuh puluh dua juta rupiah) sebagaimana dakwaan jaksa. Akan tetapi, hakim menjatuhkan pidana bersyarat terhadap terdakwa (V) dengan pidana penjara selama 6 bulan dengan masa percobaan 1 (satu) tahun.

Ketentuan pidana bersyarat diatur dalam Pasal 14a KUHP sebagai berikut: (1) Apabila hakim menjatuhkan pidana paling lama satu tahun atau pidana kurungan, tidak termasuk pidana kurungan pengganti maka dalam putusnya hakim dapat memerintahkan pula bahwa pidana tidak usah dijalani, kecuali jika dikemudian hari ada putusan hakim yang menentukan lain, disebabkan karena si terpidana melakukan suatu tindak pidana sebelum masa percobaan yang ditentukan dalam perintah tersebut diatas habis, atau karena si terpidana selama masa percobaan tidak memenuhi syarat khusus yang mungkin ditentukan lain dalam perintah itu.

(2) Hakim juga mempunyai kewenangan seperti di atas, kecuali dalam perkaraperkara yang mangenai penghasilan dan persewaan negara apabila menjatuhkan pidana denda, tetapi harus ternyata kepadanya bahwa pidana denda atau perampasan yang mungkin diperintahkan pula akan sangat memberatkan si terpidana. Dalam menerapkan ayat ini, kejahatan dan

5) Andi Hamzah, Bunga Rampai Hukum Pidana dan Acara Pidana. (Jakarta: Ghalia Indonesia, 2001), hal. 3 
pelanggaran candu hanya dianggap sebagai perkara mengenai penghasilan negara, jika terhadap kejahatan dan pelanggaran itu ditentukan bahwa dalam hal dijatuhkan pidana denda, tidak diterapkan ketentuan Pasal 30 Ayat (2).

(3) Jika hakim tidak menentukan lain, maka perintah mengenai pidana pokok juga mengenai pidana pokok juga mengenai pidana tambahan.

(4) Perintah tidak diberikan, kecuali hakim setelah menyelidiki dengan cermat berkeyakinan bahwa dapat diadakan pengawasan yang cukup untuk dipenuhinya syarat umum, bahwa terpidana tidak akan melakukan tindak pidana, dan syarat-syarat khusus jika sekiranya ditetapkan.

Hakim seharusnya dapat memberikan hukuman yang lebih optimal kepada terdakwa, mengingat tindak pidana penganiayaan yang dilakukan tersebut mengakibatkan penderitaan fisik pada korban LA, sebagaimana di sebutkan dalam Visum Et Refertum Nomor: P.002/VER/MRD/III/2012 yang ditanda tangani oleh Dr. Gloriana Ichsan dokter pada Rumah Sakit Eka Bumi Serpong Damai dengan hasil pemeriksaan sebagai berikut:

1. Daerah mata kanan terdapat memar pada kelopak mata kanan atas dan bawah berukuran empat sentimeter dan terdapat luka lecet pada kelopak mata bawah berukuran dua sentimeter kali satu sentimeter.

2. Pada lengan bawah kiri terdapat luka lecet berbentuk garis memanjang sebanyak dua buah dengan panjang sepuluh sentimeter.

3. Pada lengan bawah kanan terdapat tiga buah luka lecet bervariasi dengan ukuran nol koma lima sampai dua sentimeter.

4. Pada bagian belakang telinga kiri tampak bengkak, tidak terdapat nyeri tekan

Penjatuhan pidana bersyarat berupa pidana penjara selama 6 bulan dengan masa percobaan 1 tahun, sebagaimana diputuskan hakim tersebut relatif kurang sensitif terhadap penderitaan korban akibat tindak pidana penganiayaan oleh terdakwa. Selain itu penganiayaan ini dilakukan bersama-sama oleh terdakwa dengan anaknya di tempat umum yaitu di salah satu Minimarket di Kota Tangerang.

Berdasarkan uraian di atas, maka isu hukum dalam perkara penganiayaan anak di bawah umur dalam perkara Putusan Nomor 2298/Pid.Sus/2012/PN.TNG, 
adalah hakim mengabaikan aspek kerugian dan penderitaan fisik yang dialami korban sebagai akibat tindak pidana penganiayaan. Korban yang sudah menderita baik secara fisik karena luka-luka lebam, kerugian material untuk biaya rumah sakit serta waktu yang menjadikan korban tidak dapat mengikuti pelajaran sekolah.

Pidana bersyarat yang dijatuhkan hakim juga tidak memberikan efek jera kepada pelakunya dan tidak dapat dijadikan sebagai pembelajaran bagi pihak lain yang berpotensi melakukan tindak pidana agar tidak melakukan hal tersebut. Harapan pihak korban, terdakwa dipidana penjara (kurungan badan) sebagai bentuk pertanggungjawaban atas perbuatan yang dilakukannya. Namun demikian, hakim memutus sebaliknya dengan menerapkan pidana bersyarat terhadap pelaku. Hakim memang diberi kewenangan untuk memutus perkara dengan berbagai pertimbangan. Dalam kasus penganiayaan ini, hakim setidaknya dalam membuat putusan harus memperhatikan segala aspek di dalamnya, yaitu mulai dari perlunya kehati-hatian serta dihindari sedikit mungkin ketidak cermatan, baik bersifat formal maupun materiil sampai dengan adanya kecakapan teknik dalam membuatnya. Hakim yang cermat dan hati-hati dalam merumuskan putusannya tersebut akan menghasilkan putusan yang benar-benar berlandaskan pada keadilan dan memenuhi aspek kepastian hukum. ${ }^{6}$

Putusan hakim mempertaruhkan citra hakim di mata masyarakat, sebab putusan yang tidak menimbulkan rasa keadilan akan memunculkan cemoohan terhadap hakim, meskipun dengan dalih berdasarkan bukti-bukti yang diajukan beserta keyakinannya hakim sudah maksimal memeriksa perkara yang bersangkutan. Hakim sering lupa dalam memeriksa suatu perkara, dianggapnya perkara tersebut adalah perkara-perkara yang sama saja satu dengan yang lain. Fungsi hakim adalah memberikan putusan terhadap perkara yang diajukan, di mana dalam perkara pidana, hal itu tidak terlepas dari sistem pembuktian negatif, yang pada prinsipnya menetukan bahwa suatu hak atau peristiwa atau kesalahan dianggap telah terbukti, di samping adanya alat-alat bukti menurut undang-undang

\footnotetext{
6) Ibid, hal. 47.
} 
juga ditentukan keyakinan hakim yang dilandasi dengan integritas moral yang baik. $^{7}$

Seseorang akan dipertanggungjawabkan atas tindakan-tindakan tersebut, apabila tindakan tersebut melawan hukum serta tidak ada alasan pembenar atau peniadaan sifat melawan hukum untuk pidana yang dilakukannya. Dilihat dari sudut kemampuan bertanggung jawab maka hanya seseorang yang mampu bertanggung jawab yang dapat dipertanggung-jawabkan atas perbuatannya. Artinya dasar pertanggungjawaban pidana seseorang adalah kesalahan yang dilakukannya.

Kemampuan bertanggung jawab merupakan unsur kesalahan, maka untuk membuktikan adanya kesalahan unsur tadi harus dibuktikan lagi. Mengingat hal ini sukar untuk dibuktikan dan memerlukan waktu yang cukup lama, maka unsur kemampuan bertanggung jawab dianggap diam-diam selalu ada karena pada umumnya setiap orang normal bathinnya dan mampu bertanggung jawab, kecuali kalau ada tanda-tanda yang menunjukkan bahwa terdakwa mungkin jiwanya tidak normal. Dalam hal ini, hakim memerintahkan pemeriksaan yang khusus terhadap keadaan jiwa terdakwa sekalipun tidak diminta oleh pihak terdakwa. Jika hasilnya masih meragukan hakim, itu berarti bahwa kemampuan bertanggung jawab tidak berhenti, sehingga kesalahan tidak ada dan pidana tidak dapat dijatuhkan berdasarkan asas tidak dipidana jika tidak ada kesalahan. ${ }^{8)}$

Setiap pelaku yang terbukti melakukan tindak pidana penganiayaan harus mempertanggungjawabkan perbuatannya di depan hukum dan mendapatkan pidana sesuai dengan ketentuan undang-undang. Seseorang yang melanggar hukum harus mempertanggungjawabkan perbuatannya sesuai dengan aturan hukum yang berlaku.

Berdasarkan latar belakang yang telah dibahas, peneliti bermaksud ingin membahas mengenai apakah putusan tersebut sudah sesuai dengan hukum yang berlaku dalam bentuk penulisan skripsi dengan judul: “Analisis Putusan Pidana

7) Ahmad Rifai, Penemuan Hukum oleh Hakim dalam Persfektif Hukum Progresi, (Jakarta: Sinar Grafika, 2010), hal. 92.

8) Ibid., hal. 49. 
Bersyarat Dalam Kasus Penganiayaan Anak di Bawah Umur (Studi Putusan Nomor 2298/PID.SUS/2012/PN. TNG)".

B. Permasalahan

Berdasarkan fakta yang menjadi latar belakang sebagaimana diuraikan di atas, maka penulis merumuskan permasalahan sebagai berikut:

1. Bagaimanakah kualifikasi bisa diputus sebagai pidana bersyarat dalam kasus penganiayaan pada perkara Nomor 2298/PID.SUS/2012/PN.TNG?

2. Bagaimana bentuk perlindungan hukum dari pihak si korban?

\section{ANALISIS}

A. Kualifikasi Putusan Pidana Bersyarat dalam Kasus Penganiayaan Pada Perkara Putusan Nomor 2298/PID.SUS/2012/PN.TNG

Dalam sejarahnya, pidana bersyarat yang berlaku di Indonesia saat ini tidak lepas dari masuknya hukum Belanda yang telah diterapkan sejak masa kolonialisme. Dengan demikian, hukum Belanda memiliki pengaruh yang sangat luar biasa dalamnya pada hukum Indonesia seperti halnya dengan masuknya lembaga pidana bersyarat ke dalam Hukum Pidana Belanda dan kemudian hukum pidana Indonesia yang merupakan dampak dari pertumbuhan lembaga-lembaga semacam ini di Amerika Serikat, Inggris, dan Eropa Barat. ${ }^{9)}$ Lembaga seperti ini pertama kali muncul di Amerika Serikat pada tahun 1887, dengan nama probation. Melalui lembaga ini dimungkinkan untuk menunda penjatuhan pidana dengan cara menempatkan terdakwa dalam masa percobaan (probation) dengan pengawasan seorang probation officer.

Pidana bersyarat diberlakukan di Indonesia dengan Staatblad 1926 No. 251 jo 486, pada bulan Januari 1927 yang kemudian diubah dengan Staatblad No. 172. Bahwa pidana bersyarat merupakan lembaga yang baru, lahirnya lembaga pidana bersyarat ini di dorong oleh pikiran-pikiran baru tentang pencegahan kejahatan. Dengan adanya lembaga ini menimbulkan suatu perubahan dalam suatu

\footnotetext{
9) Muladi, Lembaga Pidana Bersyarat, (Bandung : Alumni, 1992), hal. 33.
} 
stelsel pidana. Melihat kepada hasilnya di Belanda rupanya di sana kelihatan banyak faedah dari lembaga ini. Hakimpun semakin sering menggunakan pidana bersyarat ini. Salah satu kebaikan-kebaikan pokok daripada pidana bersyarat ini adalah justru bahwa pengurungan mereka di dalam rumah penjara, dengan pengaruhnya yang merusak atas kehidupan kekeluargaan dan kemasyarakatan mereka itu, dapat dihindarkan. ${ }^{10)}$

Pengaturan mengenai pidana bersyarat ini sendiri di dalam KUHP terdapat pada Pasal 14a-14f KUHP. Walaupun disebut sebagai pidana bersyarat, pidana bersyarat bukanlah merupakan salah satu dari jenis pidana sebagaimana yang tercantum dalam Pasal 10 KUHP. Oleh sebab itu pidana bersyarat lebih cocok disebut sebagai sistem pemidanaan tertentu (Penjara) dimana ditetapkan dalam amar putusan bahwa pidana yang dijatuhkan tersebut tidak perlu dijalankan oleh terdakwa dengan syarat-syarat tertentu yang telah ditetapkan hakim.

Dalam praktek di peradilan pidana, seringkali ditemukan hakim pengadilan menjatuhkan pidana bersyarat atau dapat disebut sebagai pidana percobaan terhadap pelaku tindak pidana. Pidana bersyarat adalah suatu sistem penjatuhan pidana oleh hakim yang pelaksanaannya bergantung pada syarat-syarat tertentu atau kondisi tertentu, ${ }^{11)}$ yang dalam praktik hukum disebut dengan pidana/hukuman percobaan yaitu sistem penjatuhan pidana oleh hakim yang pelaksanaannya bergantung pada syarat-syarat tertentu atau kondisi tertentu. ${ }^{12)}$

Hal ini sebagaimana yang terjadi dalam kasus penganiayaan anak di bawah umur dalam perkara Putusan Nomor 2298/PID.SUS/2012/PN.TNG. Hakim memutus pidana bersyarat kepada pelaku, sedangkan pihak korban menginginkan pelaku dihukum seberat-beratnya karena akibat penganiayaan tersebut korban menderita luka-luka dan memar di bagian tubuhnya sehingga tidak dapat menjalankan aktivitas seperti biasanya. Dalam perkara ini, pelaku dijerat dengan Pasal Pasal 80 Ayat (2) Undang-Undang Nomor 23 Tahun 2002 tentang Perlindungan Anak jo Pasal 55 Ayat 1 ke-1 KUHP dan Pasal Pasal 80 Ayat (1)

\footnotetext{
${ }^{10)}$ Roeslan Saleh, Stelsel Pidana Indonesia, (Jakarta : Aksara Baru, 1983), hal.31.

${ }^{11)}$ Penulis, Wawancara dengan Andre Sitanggang, Advokat di Jakarta, 21 April 2018.

12) Penulis, Wawancara dengan Boedhi Prasetyo, selaku dosen Viktimologi FH Untar, Tangerang, 9 Mei 2018.
} 
Undang-Undang Nomor 23 Tahun 2002 tentang Perlindungan Anak jo Pasal 55 Ayat 1 ke-1 KUHP.

Secara umum dalam penjatuhan pidana bersyarat sebagai alternatif pemidanaan itu sendiri, seorang hakim tentu berpatokan pada ketentuan Pasal 14 huruf a sampai f KUHP yang menjadi landasan pengambilan keputusan berkaitan dengan ketentuan pidana bersyarat. Akan tetapi dalam pasal-pasal tersebut tidak disebutkan secara rinci berkenaan dengan kualifikasi atau kriteria-kriteria khusus bagi terdakwa/pelaku tindak pidana yang seperti apa yang patut dijatuhi pidana bersyarat, karena dalam ketentuan Pasal 14 a-f KUHP hanya memberikan penjelasan bahwa pidana bersyarat dapat dijatuhkan kepada pelaku tindak pidana apabila hukuman pidana yang dijatuhkan oleh hakim tidak lebih dari 1 (satu) tahun. Oleh sebab itu dalam prakteknya seorang hakim, menjatuhkan pidana bersyarat murni bergantung pada hati nuraninya sendiri dan fakta-fakta yuridis yang ditemukan dalam persidangan atas suatu perkara yang di adilinya tersebut. Begitupun pada perkara Putusan Nomor 2298/PID.SUS/2012/PN.TNG, pidana bersyarat yang dijatuhkan tidak lepas dari pertimbangan hakim baik pertimbangan yuridis maupun non yuridis dan keyakinan hakim dalam memutus sebuah perkara. Bahkan pertimbangan dari diri pelaku pada saat proses persidangan pun dapat mempengaruhi berat ringannya hukuman.

Dalam putusan pidana bersyarat kasus penganiayaan anak pada perkara Putusan Nomor 2298/PID.SUS/2012/PN.TNG, dapat dilihat dari pertimbanganpertimbangannya. Dalam putusan tersebut tidak terdapat hal-hal yang memberatkan, hakim lebih melihat pada pertimbangan yang meringankan pelaku. Hal-hal yang meringankan dalam pertimbangan hakim tersebut antara lain:

1. Dalam persidangan pelaku bersikap sopan;

2. Dalam perisdangan pelaku menyesali perbuatannya;

3. Pelaku belum pernah di hukum;

4. Pelaku sudah meminta maaf kepada korban dan keluarga korban; dan

5. Pada sata kasus ini disidangkan, pelaku memiliki seorang anak balita yang membutuhkan ASI dari ibunya. 
Dari kelima pertimbangan tersebut, majelis hakim memutuskan pelaku dinyatakan bersalah melakukan tindak pidana kekerasan terhadap anak dengan manjatuhkan hukuman pidana penjara selama 6 (enam) bulan. Meskipun dinyatakan bersalah, namun hakim memerintahkan pidana tersebut tidak perlu dijalani kecuali dikemudian hari dengan putusan hakim diberikan perintah lain atas alasan bahwa sebelum masa percobaan selama 1 (satu) tahun dan 6 (enam) bulan. Pelaku bersalah melakukan tindak pidana penganiayaan dengan kekerasan karena melanggar ketentuan Pasal 80 Ayat (1) dan Ayat (2) Undang-Undang Nomor 23 Tahun 2002 tentang Perlindungan Anak, yang menyatakan bahwa:

(1) Setiap orang yang melakukan kekejaman, kekerasan atau ancaman kekerasan, atau penganiayaan terhadap anak, dipidana dengan pidana penjara paling lama 3 (tiga) tahun 6 (enam) bulan dan/atau denda paling banyak Rp 72.000.000,00 (tujuh puluh dua juta rupiah).

(2) Dalam hal anak sebagaimana dimaksud dalam ayat (1) luka berat, maka pelaku dipidana dengan pidana penjara paling lama 5 (lima) tahun dan/atau denda paling banyak Rp 100.000.000,00 (seratus juta rupiah).

Putusan hakim merupakan puncak dari perkara pidana, sehingga hakim harus mempertimbangkan aspek-aspek lainnya selain dari aspek yuridis, sehingga putusan hakim tersebut lengkap mencerminkan nilai-nilai sosiologis, filosofis, dan yuridis. Pada hakikatnya dengan adanya pertimbangan-pertimbangan tersebut diharapkan nantinya dihindari sedikit mungkin putusan hakim menjadi batal demi hukum karena kurang pertimbangan hukum.

Seorang hakim harus dapat memutus perkara sesuai atas apa yang telah dilakukannya serta fakta-fakta yang terungkap di persidangan, seorang hakim dalam menjatuhkan putusan harus memiliki suatu pertimbangan-pertimbangan terlebih dahulu, dakwaan atau tuntutan jaksa merupakan salah satu dasar pertimbangan bagi hakim sebelum menjatuhkan pidana. Jika terdapat kesamaan pandangan antara jaksa dan hakim, maka hakim akan menjatuhkan pidana sama dengan tuntutan jaksa, sebaliknya jika tidak terdapat kesamaan pandangan antara jaksa dan hakim maka hakim dapat menjatuhkan pidana dibawah atau lebih ringan dari tuntutan jaksa atau melebihi tuntutan jaksa, hakim dalam menjatuhkan pidana 
akan mengacu pada hal-hal yang terbukti dan berdasarkan alat bukti di pengadilan.

Seperti yang dijelaskan di atas, bahwa tidak ada kualifikasi atau kriteriakriteria tertentu bagi terdakwa/pelaku tindak pidana yang seperti apa yang patut dapat dijatuhi pidana bersyarat. Dalam ketentuan Pasal 14 a-f KUHP hanya memberikan penjelasan bahwa pidana bersyarat dapat dijatuhkan kepada pelaku tindak pidana apabila hukuman pidana yang dijatuhkan oleh hakim tidak lebih dari 1 (satu) tahun. Apabila melihat kasus tersebut, bahwa pelaku dikenakan hukuman penjara selama 6 (enam) bulan, maka mengacu pada syarat dijatuhkannya pidana bersyarat, maka putusan hakim telah memenuhi dengan kriteria ditetapkannya pidana bersyarat karena hukumannya tidak melebihi dari 1 (satu) tahun.

Dengan demikian dapat dikatakan bahwa putusan pidana bersyarat merupakan kewenangan hakim yang didasarkan pada ketentuan Pasal 14 a-f KUHP dan pertimbangan-pertimbangan lain dalam persidangan. Tidak ada kualifikasi khusus dalam sebuah perkara pidana yang dapat dijadikan dasar sebuah kasus dapat dipidana dengan pidana bersyarat. Penulis berpendapat bahwa ketentuan Pasal 14a-f KUHP merupakan dasar yang dapat dijadikan pijakan hakim untuk memutus pidana bersyarat. Batasan ini menurut penulis masih sangat besar memberikan kewenangan kepada hakim karena pedoman ini menentukan ukuran dapat dipakainya pidana bersyarat adalah pada sanksi maksimal yang dijatuhkan hakim, sehingga masih tetap bergantung pada penilaian hakim.

Dalam hal kasus tindak pidana penganiayaan terhadap anak di bawah umur dalam perkara putusan Nomor 2298/Pid.Sus/2012/PN.TNG, hakim memiliki pertimbangan terhadap kualifikasi pidana yang dijatuhkan, tentu dengan melihat perbuatan yang telah dilakukan terdakwa termasuk akibat dari perbuatannya terhadap korban. Terjadinya peristiwa penganiayaan tentu ada sebabnya. Hal ini sebagaimana yang dikemukakan Boedhi Prasetyo bahwa hakim dapat melihat keterlibatan korban yang kemudian akan dijadikan pertimbangan dalam pengambilan keputusan. Disinilah hakim akan memutus perkara berdasarkan sebab akibat dan juga melihat isi pelaku dan korban karena dalam prespektif 
viktim, ada korban yang proaktif victim, murni benar-benar korban dan korban karena ada faktor pemicu. ${ }^{13)}$ Dari peristiwa itulah menunjukkan kasus penganiayaan tidak begitu saja tanpa sebab. Berdasarkan hal itulah yang kemudian oleh hakim dapat dijadikan pertimbangan dalam memutus suatu perkara pidana dapat tidaknya pelaku dikenakan pidana bersyarat karena pidana bersyarat dapat diputuskan tentu ada alasan-alasan tertentu.

Berdasarkan keseluruhan uraian di atas, maka dalam kasus ini dapat dilihat bahwa hakim dalam menjatuhkan putusan pidana bersyarat didasarkan pada undang-undang yang berlaku dan keyakinan hakim berdasarkan fakta dan bukti dalam persidangan. Dasar pertimbangan bagi hakim dalam menjatuhkan pidana bersyarat dalam perkara tindak pidana penganiayaan terhadap anak di bawah umur adalah didasarkan pada faktor sosiologis/nonyuridis sehingga penjatuhan pidana bersyarat dalam perkara tindak pidana penganiayaan ini lebih tergantung pada hati nurani hakim apakah mau menjatuhkan pidana bersyarat atau tidak. Hakim menjatuhkan pidana bersyarat didasarkan pada faktor yuridis yaitu Pasal 14a KUHP dan faktor non-yuridis yaitu dengan pertimbangan hal-hal yang meringankan seperti bersikap sopan, menyesali perbuatannya, tidak pernah dihukum, telah meminta maaf kepada korban dan keluarga korban serta pelaku memiliki seorang anak balita yang butuh ASI untuk menyusui anaknya.

\section{B. Bentuk Perlindungan Hukum dari Pihak Korban}

Tujuan pemidanaan diantaranya adalah untuk memenuhi rasa keadilan, melindungi masyarakat (social defence), melindungi kepentingan individu (HAM) dan kepentingan masyarakat serta untuk menyelesaikan konflik. Dalam teori tujuan pemidanana bahwa tujuan dari pemidanaan terletak pada pemberian pembalasan kepada terpidana atas tindak pidana yang dilakukan, tetapi untuk melindungi kepentingan masyarakat atau korban. ${ }^{14)}$

Perlindungan kepada korban tindak pidana merupakan bagian dari perlindungan hukum bagi warga negara Indonesia. Hak untuk mendapatkan

\footnotetext{
${ }^{13}$ Penulis, Wawancara dengan Boedhi Prasetyo, Op.Cit.

14) Andi Hamzah, Sistem Pidana dan Pemidanaan di Indonesia, (Jakarta: Pradnya Paramita, 1993), hal. 26.
} 
keadilan oleh korban merupakan hak asasi yang sangat mendasar dimana setiap orang berhak atas pegakuan, jaminan, perlindungan dan perlakuan hukum yang adil serta mendapat kepastian hukum dan perlakuan yang sama di depan hukum. ${ }^{15)}$ Setiap orang diakui sebagai manusia pribadi yang berhak menuntut dan memperoleh perlakuan serta perlindungan yang sama sesuai dengan martabat kemanusiaannya di depan hukum. ${ }^{16)}$

Perlindungan hukum bagi masyarakat atau korban sangatlah penting karena masyarakat baik kelompok maupun perorangan dapat menjadi korban atau bahkan sebagai pelaku kejahatan. Perlindungan hukum terhadap korban kejahatan sebagai bagian dari perlindungan terhadap masyarakat dapat diwujudkan dalam berbagai bentuk, seperti melalui pemberian restribusi dan kompensasi, pelayanan medis, dan bantuan hukum.

Hukum pidana tidak hanya berorintasi keadilan dari aspek pelaku kejahatan dan memberi keadilan bagi korban dengan cara penjatuhan sanksi yang berat (sebagai pemenuhan kepuasan psikologis korban yang telah memderita baik secara fisik dan psikis), tetapi justru yang sangat diharapkan oleh korban adalah pemulihan kerugian atas penderitaan yang dialami akibat kejahatan yang menimpanya.

Proses peradilan pidana saat ini masih berorientasi kepada retributif justice dan melalui pendekatan viktimologi, hal tersebut memunculkan gugatan terhadap hukum pidana dan penyelenggaraan peradilan yang berorientasi kepada pelaku kejahatan dengan mempertanyakan mengapa keadilan justru diberikan kepada orang yang melanggar hukum pidana dan tidak kepada orang yang terlanggar haknya, sebagai pihak yang menderita atau dirugikan secara langsung akibat adanya pelanggaran hukum pidana. ${ }^{17)}$

Realitanya keberpihakan hukum terhadap pelaku tidak seimbang dengan keberpihakan hukum terhadap korban. Beberapa peraturan perundang-undangan baik hukum pidana materil maupun hukum pidana formil lebih banyak

\footnotetext{
${ }^{15)}$ Undang-Undang Nomor 39 Tahun 1999 tentang Hak Asasi Manusia, Pasal 3 ayat (2).

16) Ibid, Pasal 5 ayat (1).

17) Mudzakkir, Viktimologi (Studi Kasus di Indonedia), Makalah dalam Seminar Nasional
} Hukum Pidana dan Kriminologi Ke XI, Surabaya, 2005. hlm. 20. 
memberikan keistimewaan dan hak-hak perlindungan hukum kepada pelaku kejahatan selaku tersangka, terdakwa dan terpidana. Korban kejahatan seakan dimarginalkan dan tidak mendapat jaminan maksimal atas hak-hak pemulihan kerugian yang dialaminya.

Dalam kasus tindak pidana penganiayaan dalam perkara putusan Nomor 2298/Pid.Sus/2012/PN.TNG, korban merupakan pihak yang dirugikan karena secara langsung telah terganggu baik secara fisik menderita luka-luka dan memar di bagian tubuhnya sehingga tidak dapat menjalankan aktivitas seperti biasanya maupun secara psikis yang berakibat trauma atas kejadian penganiayaan. Begitupula kerugian materi yang harus dikeluarkan untuk biaya pengobatan rumah sakit dan biaya-biaya lain selama proses persidangan untuk membayar pengacara dan sebagainya. Oleh karena itu, korban berhak mendapatkan perlindungan sebagai pihak yang dirugikan oleh suatu tindakan kejahatan yang telah dilakukan oleh pelaku. Namun demikian realitasnya berbeda, hakim memutus pelaku dengan pidana bersyarat sehingga putusan tersebut bagi korban tidak memberi keadilan dengan cara penjatuhan sanksi yang berat, apalagi tidak ada pemulihan kerugian atas penderitaan korban.

Korban kejahatan pada dasarnya merupakan pihak yang paling menderita akibat tindak pidana, justru tidak memperoleh perlindungan sebanyak yang diberikan oleh undang-undang kepada pelaku kejahatan. Akibatnya, pada saat pelaku kejahatan telah dijatuhi sanksi pidana oleh pengadilan, kondisi korban kejahatan seperti tidak dipedulikan sama sekali. Padahal masalah keadilan dan penghormatan hak asasi manusia tidak hanya berlaku terhadap pelaku kejahatan saja, tetapi juga korban kejahatan

Hakim memang diberi kewenangan untuk memutus perkara dengan berbagai pertimbangan, dalam kasus penganiayaan ini, hakim setidaknya perlu melihat korban sehingga dalam putusannya memberi keadilan bagi korban. Menurut pendapat penulis, pidana yang dijatuhkan terhadap pelaku tindak pidana penganiayaan yang menyebabkan kerugian bagi korban belum memenuhi unsur keadilan, sebab hakim dalam menjatuhkan pidana tidak mempertimbangkan kerugian dan penderitaan fisik yang dialami korban, tidak memberikan efek jera 
dan tidak menjadi pembelajaran bagi pihak lain agar tidak melakukan kesalahan serupa. Hal ini sesuai dengan teori keadilan legal yang dikemukakan oleh Aristoteles, yaitu perlakuan yang sama terhadap semua orang sesuai dengan hukum yang berlaku. Itu berarti semua orang harus dilindungi dan tunduk pada hukum yang ada secara tanpa pandang bulu. Keadilan legal menyangkut hubungan antara individu atau kelompok masyarakat dengan negara. Intinya adalah semua orang atau kelompok masyarakat diperlakukan secara sama oleh negara dihadapan dan berdasarkan hukum yang berlaku. Semua pihak dijamin untuk mendapatkan perlakuan yang sama sesuai dengan hukum yang berlaku. ${ }^{18}$ Hakim seharusnya dapat memberikan hukuman yang lebih optimal kepada terdakwa, mengingat tindak pidana penganiayaan yang dilakukan tersebut mengakibatkan penderitaan fisik pada korban.

Berdasarkan ketentuan Pasal 14c KUHP dalam hal hakim menjatuhkan pidana bersyarat dapat ditetapkan syarat khusus bagi terpidana untuk mengganti kerugian (semua/sebagian) yang ditimbulkan dari tindak pidana. Syarat ganti rugi seolah-olah berfungsi sebagai penganti pidana pokok. Ketentuan pasal 14 c (1) dipadang dapat memudahkan hakim untuk memperhatikan orang yang menjadi korban tindak pidana. Menurut Barda Nawawi penetapan ganti rugi ini jarang diterapkan dalam praktek karena mengandung beberapa kelemahan antara lain: ${ }^{19}$

1. Penetapan ganti rugi ini tidak dapat diberikan oleh hakim sebagai sanksi yang berdiri sendiri di samping pidana pokok, ia hanya dapat dikenakan dalam hal hakim bermaksud menjatuhkan pidana bersyarat, jadi hanya sebagai syarat khusus untuk tidak dilaksanakannya/dijalani pidana pokok yang dijatuhkan kepada terpidana.

2. Penerapan syarat khusu berupa ganti rugi inipun hanya dapat diberikan apabila hakim menjatuhkan pidana penjara paling lama satu tahun atau pidana kurungan.

${ }^{18}$ Sudikno Mertokusumo. Teori Hukum, (Jakarta: Cahaya Atma Pustaka, 2012), hal. 105106.

${ }^{19)}$ Barda Nawawi Arief, Perlindungan Korban Kejahatan Dalam Proses Peradilan Pidana, Jurnal H.P dan Kriminologi Indonesia, Volume 1 tahun 1998. hal.17. 
3. Syarat khusus berupa ganti rugi ingin menurut KUHP hanya bersifat fakultif, tidak bersifat imperative.

Salah satu instrumen hukum yang bertujuan untuk memberikan perlindungan terhadap anak baik sebagai korban maupun pelaku tindak pidana adalah Undang-Undang Nomor 35 Tahun 2014 tentang perubahan atas UndangUndang Nomor 23 Tahun 2002 tentang Perlindungan Anak. Undang-undang ini kemudian mengalami perubahan karena tuntutan zaman dan kejahatan yang dialami anak bukan hanya kekerasan fisik tetapi dibarengi dengan kekerasan seksual. Dengan pertimbangan bahwa kekerasan seksual terhadap anak semakin meningkat secara signifikan yang mengancam dan membahayakan jiwa anak, merusak kehidupan pribadi dan tumbuh kembang anak, serta mengganggu rasa kenyamanan, ketenteraman, keamanan, dan ketertiban masyarakat, pemerintah memandang sanksi pidana yang dijatuhkan bagi pelaku kekerasan seksual terhadap anak belum memberikan efek jera dan belum mampu mencegah secara komprehensif terjadinya kekerasan seksual terhadap anak.

Pemerintah pada akhirnya mengubah Undang-Undang Nomor 23 Tahun 2002 tentang Perlindungan Anak sebagaimana telah diubah dengan UndangUndang Nomor 35 Tahun 2014 tentang Perubahan atas Undang-Undang Nomor 23 Tahun 2002 tentang Perlindungan Anak. Dengan berlakunya undang-undang ini meskipun pelaku dihukum dengan pidana bersyarat, pihak korban dapat menuntut upaya ganti rugi seiring dengan dikeluarkannya Peraturan Pemerintah Nomor 43 Tahun 2017 tanggal 16 Oktober 2017 tentang Pelaksanaan Restitusi Bagi Anak Yang Menjadi Korban Tindak Pidana. Restitusi ini diharapkankan menjadi bentuk ganti rugi dan perlindungan bagi anak-anak korban kejahatan. $^{20}$

Berlakunya Peraturan Pemerintah Nomor 43 Tahun 2017 dilatarbelakangi oleh kenyataan bahwa kejahatan terhadap anak tidak hanya menimbulkan penderitaan fisik maupun psikis yang mempengaruhi tumbuh kembang dan kualitas hidup anak. Namun menimbulkan kerugian materil maupun imateriil bagi

${ }^{20)}$ Undang-Undang Nomor 35 Tahun 2014 tentang Perubahan atas Undang-Undang Nomor 23 Tahun 2002 tentang Perlindungan Anak, Pasal 71D. 
pihak keluarga. Oleh karena itu, sangatlah tepat, bila pengertian restitusi diartikan sebagai pembayaran ganti kerugian yang dibebankan kepada pelaku berdasarkan putusan pengadilan yang berkekuatan hukum tetap atas kerugianmateril dan atau imateril yang diderita korban atau ahli warisnya.

Ketentuan ini menjamin hak anak korban kejahatan untuk mendapatkan restitusi. Ditegaskan bahwa setiap anak yang menjadi korban tindak pidana berhak memperoleh restitusi. Adapun kualifikasi anak korban kejahatan yang mendapat restitusi terdiri atas Pertama anak yang berhadapan dengan hukum. Kedua anak yang dieklpoitasi secara ekonom dan/atau seksual. Ketiga anak yang menjadi korban pornografi. Keempat Anak korban penculikan, penjualan, dan/atau perdagangan. Kelima anak Korban kekerasan fisik dan/atau. Keenam anak korban kejahatan seksual. Khusus bagi anak yang berhadapan dengan hukum, restitusi diberikan kepada anak korban. Restitusi yang diberikan kepada anak yang berhadapan dengan hukum berupa ganti kerugian atas kehilangan kekayaan, ganti kerugian atas penderitaan sebagai akibat tindak pidana dan/atau penggantian biaya perawatan medis dan/atau psikologis.

Pengajuan restitusi dapat diajukan oleh pihak korban. Dalam hal ini pihak korban terdiri dari orang tua atau wali anak yang menjadi korban tindak pidana, ahli waris anak yang menjadi korban tindak pidana, dan orang yang diberi kuasa oleh orang tua, wali atau ahli waris anak yang menjadi korban tindak pidana dengan surat Kuasa Khusus. Jika pihak yang mengajukan restitusi terlibat sebagai pelaku, maka pengajuan restitusi dapat dilakukan oleh Lembaga Perlindungan Saksi dan Korban (LPSK).

Permohonan restitusi diajukan secara tertulis di atas materai ke Pengadilan. Permohonan tersebut dapat diajukan dalam tahap penyidikan, Penuntutan dan pasca Putusan Pengadilan yang telah mendapat kekuatan hukum tetap. Khusus yang terakhir ini, permohonan dapat dilakukan oleh LPSK.

Pemberian restitusi dilaksanakan dengan cara sebagai berikut: pertama panitera Pengadilan mengirimkan salinan penetapan yang berkekuatan hukum tetap yang memuat pemberian restitusi kepada Jaksa. Kedua dalam waktu tujuh hari sejak diterimanya putusan tersebut, Jaksa wajib menyampaikan kepada 
pelaku dan pihak korban. Ketiga pelaku wajib memberikan restitusi kepada pihak korban dalam jangka waktu 30 (tiga puluh) hari sejak diterimanya salinan putusan tersebut, dalam Berita Acara Pelaksanaan Putusan. Jika Pelakunya adalah anak, maka pemberian restitusi dilakukan oleh orang tuanya. Keempat, setelah pelaku memberikan restitusi kepada pihak korban, ia wajib melaporkan kepada Pengadilan dan Kejaksaan. Kelima, setelah itu Pengadilan mengumumkan pelaksanaan pemberian restitusi, baik melalui media elektronik maupun non elektronik.

Dikeluarkannya Peraturan Pemerintah ini setidaknya memberikan secercah harapan, dan mengakomodir kerugian para korban khsusnya anak yang mengalami kerugian materil maupun immatril akibat korban kejahatan yang dialaminya, dan diharapkan anak korban-korban kejahatan masih dapat menatap masa depannya atau melanjutkan sekolahnya demi masa depannya.

Apabila dikaitkan dengan kasus penganiayaan anak di bawah umur pada perkara putusan Nomor 2298/Pid.Sus/2012/PN.TNG, dimana kasus ini terjadi pada tahun 2012, maka instrumen hukum yang berlaku adalah KUHP. Dalam KUHP bentuk perlindungan yang diberikan kepada korban kejahatan terdapat dalam Pasal 14c ayat (1) berupa penetapan syarat khusus penggantian kerugian yang dialami oleh korban sebagai akibat dari tindak pidana yang harus dipenuhi oleh terpidana yang dijatuhkan pidana bersyarat. Demikian pula dalam KUHAP, perlindungan hukum terhadap korban kejahatan dirumuskan dalam beberapa hal sebagai berikut:

1. Hak sebagai pemohon praperadilan (pihak ketiga yang berkepentingan) terhadap tindakan penyidik atau penuntut umum yang menghentikan penyidikan dan/atau penuntutan (Pasal 77 jo. 80 KUHAP).

2. Hak korban untuk mengundurkan diri sebagai saksi sebagaimana kualifikasi saksi yang ditentukan dalam Pasal 168 KUHAP.

3. Hak untuk mengajukan permohonan penggabungan perkara gugatan ganti kerugian sebagaimana diatur dalam Pasal 98-101 KUHAP. Penggabungan perkara gugatan ganti kerugian ini sebagai implementasi asas peradilan cepat, sederhana dan biaya ringan. 
4. Hak bagi keluarga korban untuk mengizinkan atau tidak mengizinkan penyidik melakukan otopsi (Pasal 134-136 KUHAP).

Dalam kasus ini, meskipun instrumen hukum membuka peluang bagi korban untuk menuntut ganti rugi kepada pelaku, akan tetapi kesempatan ini tidak digunakan. Pihak korban hanya menuntut si pelaku dihukum berat saja sehingga mengabaikan tuntutan ganti rugi, demikian sebagaimana diungkapkan oleh orang tua korban. ${ }^{21)}$

\section{PENUTUP}

\section{A. Kesimpulan}

1. Tindak pidana bersyarat merupakan pidana dengan syarat-syarat tertentu yang dalam praktik hukum disebut dengan pidana percobaan yaitu sistem penjatuhan pidana oleh hakim yang pelaksanaannya bergantung pada syaratsyarat tertentu atau kondisi tertentu. Pertimbangan hukum hakim dalam menjatuhkan pidana bersyarat pada kasus penganiayaan anak di bawah umur dalam perkara putusan Nomor 2298/Pid.Sus/2012/PN.TNG, di dasarkan pada faktor yuridis yaitu Pasal 14a KUHP dan faktor non-yuridis yaitu keyakinan hakim dan pertimbangan terhadap hal-hal yang meringankan seperti bersikap sopan, menyesali perbuatannya, tidak pernah dihukum, telah meminta maaf kepada korban dan keluarga korban serta pelaku memiliki seorang anak balita. Tidak ada kualifikasi khusus bagi pelaku tindak pidana yang seperti apa yang patut dapat dijatuhi pidana bersyarat. Hakim dapat memutus pidana bersyarat hanya didasarkan pada Pasal 14 a-f KUHP yang dalam penjelasannya bahwa pidana bersyarat dapat dijatuhkan kepada pelaku tindak pidana apabila hukuman pidana yang dijatuhkan oleh hakim tidak lebih dari 1 (satu) tahun. Dalam perkara ini putusan hakim telah memenuhi kriteria ditetapkannya pidana bersyarat karena hukumannya tidak melebihi dari 1 (satu) tahun.

\footnotetext{
${ }^{21)}$ Penulis, Wawancara dengan Albert Tandanu, selaku orangtua korban, Tangerang, 3 Mei 2018.
} 
2. Bentuk perlindungan hukum terhadap anak korban tindak pidana penganiayaan instrumen hukumnya telah di atur dalam beberapa peraturan perundang-undangan. Pasal 14c KUHP dalam hal hakim menjatuhkan pidana bersyarat dapat ditetapkan syarat khusus bagi terpidana untuk mengganti kerugian (semua/sebagian) yang ditimbulkan dari tindak pidana dan Pasal 71D Undang-Undang Nomor 35 Tahun 2014 tentang Perlindungan Anak jo Peraturan Pemerintah Nomor 43 Tahun 2017, bahwa setiap anak yang menjadi korban tindak pidana berhak memperoleh restitusi atau ganti rugi. Anak menjadi korban tindak pidana antara lain anak yang berhadapan dengan hukum, anak yang dieksploitasi secara ekonomi atau seksual, anak yang menjadi korban pornografi, anak korban penculikan, penjualan atau perdagangan, anak korban kekerasan fisik atau psikis dan anak korban kejahatan seksual. Dalam kasus perkara Nomor 2298/Pid.Sus/2012/PN.TNG, meskipun instrumen hukum membuka peluang bagi korban untuk menuntut ganti rugi kepada pelaku, akan tetapi kesempatan ini tidak digunakan. Pihak korban hanya menuntut si pelaku dihukum berat saja sehingga mengabaikan tuntutan ganti rugi.

\section{B. Saran}

1. Bagi penegak hukum diharapkan lebih objektif dalam menyelesaikan suatu perkara tindak pidana penganiayaan terhadap anak di bawah umur, khususnya Majelis Hakim dalam menjatuhkan suatu pidana lebih mempertimbangkan lagi pemidanaan yang cocok untuk pelaku, agar suatu pemidanaan sejalan dengan tujuan pemidanaan sebagai pendidikan yang tentunya tanpa mengurangi hak dari si korban sebagai pemenuhan rasa keadilan.

2. Dalam penanganan kasus tindak pidana penganiayaan terhadap anak di bawah umur atau tindak pidana lain, hendaknya penegak hukum dalam hal ini pihak kepolisian maupun jaksa sebelum kasus naik ke pengadilan memberitahukan kepada pihak korban akan hak-haknya sehingga pada saat kasus diajukan ke pengadilan agar bisa mengajukan permohonan restitusi. Hal ini dikarenakan masyarakat masih awam tentang permohonan restitusi yang syaratnya 
diajukan sebelum putusan pengadilan yakni di tahap penyidikan atau penuntutan.

\section{DAFTAR PUSTAKA}

\section{A. Buku:}

Amrullah, M. Arief. Politik Hukum Pidana dalam Perlindungan Korban Kejahatan Ekonomi di Bidang Perbankkan. (Malang: Bayu Media, 2003).

Bentham, Jeremy. Teori Perundang-Undangan Prinsip-Prinsip Legislasi, Hukum Perdata dan Hukum Pidana. (Bandung: Penerbit Nusamedia Penerbit Nuansa, 2006).

Edelhertz, Herbert \& Gilbert Geis. Public Compensation to Victim of Crime. (New York: Praeger Publisher, 1974).

Galtung, Johan. Kekuasaan dan Kekerasan Menurut Johan Galtung, Cet. 1 (Yogyakarta: Penerbit Kanisius, 1992).

Gandasubrata, Purwoto S. Masalah Ganti Rugi Dalam/Karena Perkara Pidana,"Penegakan Hukum Dalam Mensukseskan Pembangunan, (ed.) Badan Kontak Profesi Hukum Lampung, (Bandung: Alumni, 1977).

Gosita, Arif. Masalah Korban Kejahatan. (Jakarta: Akademika Pressindo, 1993). . Masalah Perlindungan Anak. (Jakarta, Bhuana Ilmu Populer, 2004).

Gultom, Binsar M. Pandangan Kritis Seorang Hakim dalam Penegakan Hukum di Indonesia, Cetakan Pertama. (Jakarta: Kompas Gramedia, 2012).

Perlindungan Hukum Terhadap Anak dan Perempuan. (Bandung: Refika Aditama, 2014).

Hamzah, Andi. Sistem Pidana dan Pemidanaan di Indonesia. (Jakarta: Pradnya Paramita, 1993).

. Asas-asas Hukum Pidana, Edisi Revisi. (Jakarta: PT Rineka Cipta, 1994).

Bunga Rampai Hukum Pidana dan Acara Pidana. (Jakarta: Ghalia Indonesia, 2001). 
Kusumah, Mulyana W. (ed). Hukum dan Hak-Hak Anak Dalam Aspek Hukum Prerrlindungan Anak atas Hak-Hak Anak. (Jakarta: Rajawali, 1968).

Lamintang, P.A.F. Hukum Penitensier Indonesia. (Bandung: Amrico, 1984).

Marzuki, Peter Mahmud. Penelitian Hukum. (Jakarta: Kencana Prenada Media Grup).

Mertokusumo, Sudikno. Teori Hukum. (Jakarta: Cahaya Atma Pustaka, 2012).

Moeljatno. Kitab Undang-Undang Hukum Pidana. (Jakarta: PT. Bumi Aksara, 2008).

Saleh, Roeslan. Stelsel Pidana Indonesia. (Jakarta: Aksara Baru, 1983).

Muladi. Lembaga Pidana Bersyarat. (Bandung: Alumni, 1992).

Poernomo, Bambang. Pelaksanaan Pidana Penjara dengan Sistem Pemasyarakatan. (Yogyakarta: Liberty, 2002).

Prinst, Darwan. Hukum Anak Indonesia. (Bandung: Citra Adiya Bhakti, 1997).

Rifai, Ahmad. Penemuan Hukum oleh Hakim dalam Persfektif Hukum Progresi. (Jakarta: Sinar Grafika, 2010).

Reksodiputro, Mardjono. Kriminologi dan Sistem Peradilan Pidana. Cetakan Pertama (Edisi Pertama). (Jakarta: Pusat Pelayanan Keadilan dan Pengabdian Hukum (d/h Lembaga Kriminologi) Universitas Indonesia, 1994).

Santoso, Agus. Hukum, Moral dan Keadilan, Cetakan ke-2. (Jakarta: Kencana Prenada Media Group, 2014).

Saleh, Roeslan. Hukum Pidana Sebagai Konfrontasi Manusia dan Manusia. Cetakan Pertama. (Jakarta: Ghalia Indonesia, 1983).

Setyawati, Melly dan Supriyadi Widodo Eddyono, Perlindungan Anak dalam Rancangan KUHP. (Jakarta: ELSAM dan Aliansi Nasional Reformasi KUHP, 2007).

Soeaidy, Zulkhoir Sholeh. Dasar Hukum Perlindungan Anak. Cetakan ke-1. (Jakarta: Novindo Pustaka Mandiri, 2001).

Soemitro, Irma Setyowati. Aspek Hukum Perlindungan Anak. (Jakarta: Bumi Aksara, 1990).

Soesilo, R. Pokok-pokok Hukum Pidana. (Bogor: Politea, tanpa tahun). 
Suherman, Ade Maman dan J. Satrio, Penjelasan Hukum Tentang Batasan Umur (Kecakapan dan Kewenangan Bertindak Berdasar Batasan Umur). (Jakarta: NLRP, 2010).

Wadong, Maulana Hassan. Pengantar Advokasi dan Hukum Perlindungan Anak. (Jakarta: PT Gramedia Wiasarana Indonesia, 2000).

Yulia, Rene. Viktimologi Perlindungan Hukum Terhadap Korban Kejahatan. (Yogyakarta: Graha Ilmu, 2009).

\section{B. Peraturan Perundang-Undangan}

Indonesia. Kitab Undang-Undang Hukum Pidana.

. Kitab Undang-Undang Hukum Acara Pidana.

. Undang-Undang Nomor 39 Tahun 1999 tentang Hak Asasi Manusia (Lembaran Negara Republik Indonesia Tahun 1999 Nomor 165; Tambahan Lembaran Negara Republik Indonesia Nomor 3886).

. Undang-Undang Nomor 13 Tahun 2006 tentang Perlindungan Saksi dan Korban. (Lembaran Negara Republik Indonesia Tahun 2006 Nomor 64; Tambahan Lembaran Negara Republik Indonesia Nomor 4635).

- Undang-Undang Nomor 23 Tahun 2002 tentang Perlindungan Anak, (Lembaran Negara Republik Indonesia Tahun 2002 Nomor 109, Tambahan; Lembaran Negara Republik Indonesia Nomor 4235).

. Undang-Undang Nomor 35 Tahun 2014 tentang Perubahan atas Undang-Undang Nomor 23 Tahun 2002 tentang Perlindungan Anak (Lembaran Negara Republik Indonesia Tahun 2014 Nomor 297; Tambahan Lembaran Negara Republik Indonesia Nomor 5606)

. Peraturan Pemerintah Nomor 3 Tahun 2002 tentang Kompensasi, Restitusi, dan Rehabilitasi Terhadap Korban Pelanggaran Hak Asasi Manusia yang Berat.

Peraturan Pemerintah Nomor 43 Tahun 2017 tentang Pelaksanaan Restitusi Bagi Anak yang Menjadi Korban Tindak Pidana.

\section{Artikel/Makalah/Jurnal}

Arief, Barda Nawawi. "Perlindungan Korban Kejahatan Dalam Proses Peradilan Pidana", Jurnal H.P dan Kriminologi Indonesia, Volume 1 tahun 1998. 
Atmasasmita, Romli. "Masalah Santunan Terhadap Korban Tindak Pidana." Majalah Hukum Nasional Departemen Kehakiman, 1992.

Eddyono, Supriyadi W. "Pengantar Konvensi Hak Anak”, Makalah, Pada kursus HAM untuk Pengacara. Lembaga Studi dan Advokasi Masyarakat, Jakarta, 2005.

Mudzakkir. Viktimologi (Studi Kasus di Indonedia), Makalah dalam Seminar Nasional Hukum Pidana dan Kriminologi Ke XI, Surabaya, 2005.

Sibuea, Harris Y. P. "Persoalan Hukum Atas Restitusi Terhadap Anak Korban Tindak Pidana", Info Singkat Hukum, Vol. IX, No. 21/I/Puslit/November/2017.

\section{Kamus}

Badudu, J.S. dan Sutan Mohammad Zain, Kamus Umum Bahasa Indonesia. (Jakarta: Pustaka Sinar Harapan, 1994).

Departemen Pendidikan Nasional. Kamus Besar Bahasa Indonesia. (Jakarta: Balai Pustaka, 2005).

Hamzah, Andi. Kamus Hukum. Cetakan Pertama. (Jakarta: Ghalia Indonesia, 1986).

Pendidikan dan Kebudayaan, Departemen. Kamus Besar Bahasa Indonesia. Edisi Kedua. (Jakarta: Balai Pustaka, 1976).

Purwodarminto, WJS. Kamus Umum Bahasa Indonesia. (Jakarta: Balai Pustaka, 1959). 